\title{
BIBLIOMETRIJSKA ANALIZA ČASOPISA «SIGURNOST» OD 2005. DO 2015. GODINE
}

UDK 001.8(051Sigurnost) „2005/2015“

PRIMLJENO: 5.4 .2017 .

PRIHVAĆENO: 6.11. 2017.

\begin{abstract}
SAŽETAK: U radu je prema osnovnim bibliometrijskim pokazateljima analiziran časopis Sigurnost u razdoblju od 2005. do 2015. godine. Uzorak je obuhvaćao 250 kategoriziranih radova objavljenih u jedanaestogodišnjem razdoblju. Analiza radova pokazala je da su najzastupljeniji pregledni radovi (32,4\%), zatim stručni radovi zastupljeni s udjelom od $32 \%$, izvorni znanstveni radovi s udjelom od 25,2\%, prethodna priopćenja s udjelom od 9,2\%, izlaganja sa skupa $s$ udjelom od 0,8\% dok je najmanje radova kategorizirano kao stručni prikaz (0,4\%). Jezik objavljenih radova uglavnom je hrvatski $(90 \%$ ), što upućuje na regionalnu orijentaciju časopisa. Časopis Sigurnost zastupljen je u multidisciplinarnoj bibliografskoj i citatnoj bazi podataka Scopus od vol. 51, 2009. godine, multidisciplinarnoj bazi podataka Academic Search Complete (ASC) iz korpusa EBSCO-vih baza podataka od 50. vol. 2008. godine. Također, u cijelosti je indeksiran u disciplinarnoj bazi podataka ProQuest Biological \& Health Science Professional od 1992. Vidljivost časopisa Sigurnost omogućena je osiguravanjem pristupa cjelovitim tekstovima objavljenih radova dostupnih preko Portala znanstvenih časopisa Republike Hrvatske - Hrčak od vol. 47 (2005), br. 1. U Hrčak je uključen 1. ožujka 2006. godine.
\end{abstract}

Ključne riječi: časopis Sigurnost, bibliometrijski pokazatelji, analiza radova, Hrvatska

\section{UVOD}

Znanost se može promatrati kao istraživački proces u kojem znanstvenici koordiniraju svoje aktivnosti kako bi različitim metodama proizveli novo znanje. Novostečeno znanje čuva se objavljivanjem u formi različitih publikacija koje predstavljaju srž znanstvene komunikacije. To su primarno članci u znanstvenim časopisima ili zbornicima skupova, knjige, patenti i razna izvješća. Znanstvenici objavljuju rezultate istraživačkog rada na prepoznatljiv način od pojave prvih znanstvenih časopisa u 17. stoljeću što pak omogućuje sustavno promatranje znanstvene li-

*Goranka Mitrović, dipl. ing./dipl. bibl., (gmitrovic@nsk.hr), mr sc. Kristina Romić, (kromic@nsk.hr), Nacionalna i sveučilišna knjižnica u Zagrebu, Hrvatske bratske zajednice 4, 10000 Zagreb. terature. Najvažnija uloga znanstvenih časopisa jest objavljivanje i diseminacija znanstvenih članaka. Znanstvena komunikacija kroz publikacije temelji se na povjerenju u pouzdanost objavljenih informacija. Pouzdanost objavljenih informacija postiže se recenzentskim postupkom. Recenzijski postupak ima, naime, ključnu ulogu u provjeri metodološke ispravnosti, interpretacije i zaključaka rezultata istraživanja opisanih u člancima. Povjerenje u pouzdanost objavljenog znanja kolega s jedne strane i zadaća propitkivanja znanstvenih informacija s druge strane, tvori kompleksne odnose povjerenja i validacije u znanosti. Na temelju kvalitete recenzijskog postupka i kvalitete objavljenih radova časopis stvara svoju reputaciju u znanstvenoj zajednici. Reputacija časopisa je znanstvenicima često jedan od prvih signala vjerodostojnosti objavljenih 
znanstvenih informacija. Recenzijski postupak je vjerojatno i jedan od ključnih razloga što se, unatoč znatnom napretku informacijskih tehnologija, objavljivanje radova u znanstvenim časopisima zadržalo kao dominantan način formalne znanstvene komunikacije u većini znanstvenih područja, a posebice u prirodnim znanostima te biomedicini i zdravstvu. Sljedeća funkcija časopisa je zaštita intelektualnog vlasništva autora, njegovo predstavljanje znanstvenoj zajednici odnosno osiguravanje puta za stjecanje profesionalnog priznanja i napredovanja (Macan, Petrak, 2015.). Broj znanstvenih časopisa u svijetu svakodnevno raste te znanstvenici nisu u mogućnosti pratiti sve što je objavljeno iz područja njihovog interesa, pa su prisiljeni selektirati literaturu za koju će izdvojiti svoje dragocjeno vrijeme. Ti razlozi naveli su knjižničare, znanstvenike i izdavače zainteresirane za procjenu kvalitete časopisa da biraju za pretplatu najrelevantnije znanstvene časopise.

Jedan od glavnih načina procjene kvalitete znanstvenog rada nekog znanstvenika, grupe znanstvenika, ustanove i sl. jest putem analize njihove znanstvene produktivnosti. $U$ znanosti je uvriježen postupak da se gotovo sva relevantna znanstvena otkrića objave putem znanstvenih publikacija i podijele s ostatkom znanstvene zajednice. Zato je temeljna pretpostavka vrednovanja znanstvenog rada da se ono može dobrim dijelom osloniti na analizu znanstvene produktivnosti, tj. bibliometrijske analize. Tvorac pojma bibliometrija, Alan Pritchard, je 1969. godine bibliometriju definirao kao primjenu matematičkih i statističkih metoda na knjige i ostale medije u znanstvenoj komunikaciji. Bibliometrijske analize temelje se na podacima o broju znanstvenih radova, njihovih citata i njihovih autora s ciljem mjerenja produkcije i odjeka pojedinaca/istraživačkih timova, ustanova i država, identificiranja nacionalnih i internacionalnih suradničkih mreža i otkrivanja novih polja znanosti i tehnologije (Macan, 2015.).

Polazište bibliometrijske koncepcije i metoda treba tražiti u najranijim nastojanjima istraživača da popišu, a zatim i temeljito opišu osnovna obilježja izvornih znanstvenih tekstova, kao i u nastojanjima istraživača da utvrde odnose i veze među znanstvenim djelima i bibliografskim jedinicama. Zbirke publikacija ili bibliografskih zapisa, najčešće u obliku radova/članaka objavljenih unutar jednog ili više znanstveno-stručnih časopisa, osnovne su jedinice na kojima se provode bibliometrijske analize (Pehar, 2010.). Bibliometrija je kvantitativna matematička i statistička analiza objavljenih radova na svim makro i mikro razinama znanstvenih komunikacija. Bibliometrija može se primijeniti na bilo kojem znanstvenom području i za većinu problema koja se bave pisanom znanstvenom komunikacijom. Osnovna postavka citatnih analiza je da su citati prebrojivi te da se iz tako kvantificiranih podataka može doći do relevantnih informacija o znanstvenoj literaturi pa tako i o znanosti i znanstvenom procesu. Bibliometrijskim istraživanjima hrvatskih časopisa bavili su se mnogi. U Hrvatskoj prva bibliometrijska istraživanja započela su u prirodnim, biomedicinskim i tehničkim znanostima (Borić, 2008., Borić, Strujić, 2006., Krajna, Petrak, 2004., Jokić, Sirotić, 2003., Andreis, Klaić, 2002., Petrak, 2001., 2001. a, Jokić, 2001., Borić, 1992.), a sve češće se analiziraju i časopisi s područja društvenih znanosti (Jokić, Zauder, 2013., Martek, Šute, 2010., Švenda Radeljak, 2006., Dukić, 1990.).

Sigurnost: časopis za sigurnost u radnoj i životnoj okolini je znanstveno-stručni časopis koji objavljuje znanstvene i stručne članke te izlazi četiri puta godišnje. Časopis počinje izlaziti 1959. godine pod naslovom Sigurnost u pogonu = Industrial safety: stručno-informativni mjesečnik za probleme sigurnosti pri radu. Od 1972. godine mijenja naslov u Sigurnost, s podnaslovom: stručno naučni časopis: zaštita pri radu, zaštita od požara, sigurnost u prometu= industrial safety, fire protection, traffic safety. Godine 1977. podnaslov se mijenja u: znanstveno-stručni časopis: zaštita pri radu, zaštita od požara, zaštita čovjekove okoline= industrial safety, fire protection, environmental protection; od 1982. do 1990. godine: znanstveno-stručni časopis: zaštita pri radu, zaštita od požara, zaštita radne i životne okoline, sigurnost u prometu = industrial safety, fire protection, environmental protection, traffic safety.

Kroz godine su se mijenjali i glavni urednici: od god. 1 (1959.) urednici: Ivan Malčić, Miroslav Pintar; od god. 4 (1962.) - god. 7 (1965.): Stevo 
Vujaković; od god. 8 (1966.): Marijan Logar; od god. 14 (1972.) urednik: Antonija Ivić; od god. 28 (1986.): Tinka Katić; god. 29, br. 3 (1987.): Željko Jakšić; god. 29, br. 4 (1987.): Dinko Stary; od god. 30 (1988.): Marina Marinović-Rajković; vol. 32, br. 4 (1990.): Lidija Švagel; od vol. 33 (1991.): Nenad Kacian; vol. 35, br. 1-2 (1993.): Krunoslav Rakoš; od vol. 35, br. 3/4(1993.): Krešimir Telebec; od vol. 37, br. 2 (1995.)-vol. 38, br. 2(1996.): Ljubica Dunaj Mutak; vol. 38, br. 3 (1996.): Krešimir Telebec; od vol. 57, br. 3 (2015.): Željko Sven Bukovski.

\section{PRISTUP ISTRAŽIVANJU I METODE}

U ovome radu prikazat će se samo određeni aspekti bibliometrijskih istraživanja. Da bi se dobila što cjelovitija slika uloge i značaja časopisa na znanstvenu zajednicu, analizirat će se kategorizirani članci, uključujući analizu autorstva i citiranih referenci. Analizom citata objavljenih radova iz ovog časopisa, prema podacima dobivenim iz citatnih indeksa WoSCC-a te Scopusa u kojoj su radovi časopisa zastupljeni od 2009., željela se utvrditi prepoznatljivost radova $u$ širem relevantnom okruženju.

U ovome radu težište će biti na analizi bibliometrijskih pokazatelja časopisa Sigurnost u jedanaestogodišnjem razdoblju (od 2005. do 2015. godine). Bit će napravljena citatna analiza časopisa na temelju podataka o citiranosti dostupnih na platformi iz Web of Science (WoS) kao nezaobilazne citatne baze podataka kada je riječ o bibliometrijskim analizama časopisa, te Scopusa, citatne baze podataka koja se pojavila 2004. godine te indeksira velik broj časopisa, među kojima je i Sigurnost.

Promatrane su i analizirane bibliografske jedinice (članci) prema određenim parametrima:

- broj članaka po godinama

- kategorizacija članaka

- broj autora i ustanova

- jezik publiciranja

- citiranost radova

- vidljivost časopisa u sekundarnim izvorima.

\section{REZULTATI I DISKUSIJA}

\section{Vrsta objavljenih radova i jezik objavljivanja}

Korištenjem bibliometrijskih metoda analizirani su svi kategorizirani članci objavljeni u časopisu tijekom jedanaestogodišnjeg razdoblja. Svi radovi, ukupno 250 kategoriziranih radova te 419 priloga (slika 1), pregledani su de visu, od 2005. do 2015. godine. Vrste radova koje su uzete kao uzorak za analizu časopisa bile su izvorni znanstveni radovi, prethodna priopćenja, pregledni radovi, stručni radovi, izlaganja sa skupa te stručni prikaz. Od ukupnog broja svih radova (250), urednici i uredništvo časopisa označili su 32,4 \% radova (81) kao pregledne radove. Stručni radovi zastupljeni su s udjelom od $32 \%$ (80 radova), izvorni znanstveni radovi s udjelom od $25,2 \%$ (63 rada), prethodna priopćenja s udjelom od 9,2\% (23 rada), izlaganja sa skupa s udjelom od $0,8 \%$ (2 rada) te stručni prikaz s udjelom od 0,4 \% (1 rad). Analiza opsežnosti radova (mjerena brojem stranica) pokazuje da je prosječna duljina radova bila 9,3 stranice (pregledni radovi imaju prosječnu duljinu 10,3 stranice, stručni radovi 8, izvorni znanstveni radovi 9,5, prethodno priopćenje 9,2, izlaganje sa skupa 8 , te stručni prikaz 13 stranica).

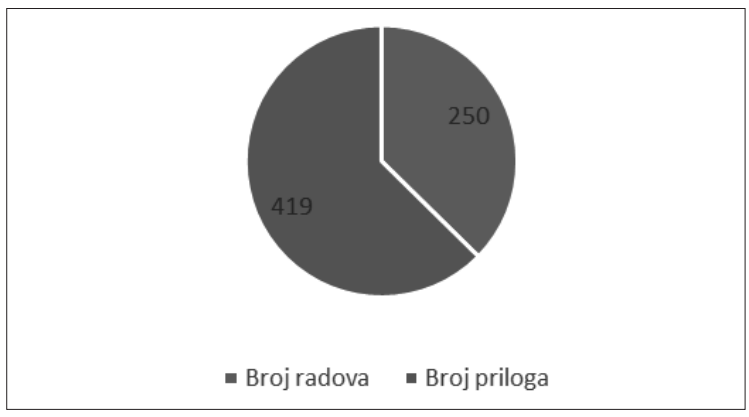

Slika 1. Broj objavljenih radova i priloga od 2005. do 2015. godine

Figure 1. Number of published categorized papers and other papers from 2005-2015

Analiza broja kategoriziranih radova na godišnjoj razini pokazuje ujednačenost. Slika 2. prikazuje kretanje broja objavljenih kategoriziranih radova i ostalih priloga po pojedinim godinama u razdoblju od 2005. godine do 2015 . godine. Maksimalni broj radova bio je 2009., 28 radova, a minimalni 2006., šesnaest radova. 
Što se tiče priloga, maksimalni broj priloga bio je 2006., 51 prilog, a minimalni 2009. godine, 22 priloga.

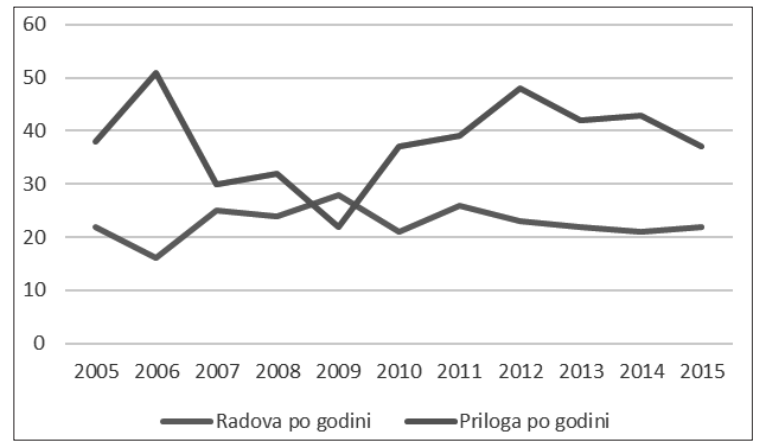

Slika 2. Broj objavljenih radova i priloga po godini od 2005. do 2015. godine

Figure 2. Number of published papers by year, 2005-2015

Jezik objavljivanja ne samo da utječe na vidljivost radova u međunarodnoj znanstvenoj zajednici, već i upućuje na otvorenost časopisa za suradnju izvan svojeg užeg okruženja. Većina članaka objavljena je na hrvatskom jeziku $(89,1 \%)$, dok je 25 kategoriziranih radova $(10,9 \%)$ objavljeno na engleskom jeziku.

U Tablici 1. prikazani su pojedinačni kategorizirani radovi te jezik kojim su pisani. Na engleskom jeziku najviše su pisana prethodna priopćenja $(25,9 \%)$ te izvorni znanstveni radovi $(12,7 \%)$. Na hrvatskom jeziku pisana su izlaganja sa skupa te stručni prikaz. Kategorizirani radovi napisani na hrvatskom jeziku imaju naslov rada, ključne riječi, naslov slika i tablica objavljene usporedno i na engleskom jeziku.

Tablica 1. Jezik kategoriziranih radova

Table 1. Language of papers

\begin{tabular}{|l|c|c|c|c||}
\hline $\begin{array}{l}\text { Jezik kategoriziranih } \\
\text { radova }\end{array}$ & hrvatski & $\mathbf{\%}$ & engleski & $\mathbf{\%}$ \\
\hline Stručni rad & 76 & 95,00 & 4 & 5,00 \\
\hline Pregledni rad & 75 & 92,60 & 6 & 7,40 \\
\hline Izvorni znanstveni rad & 55 & 87,30 & 8 & 12,70 \\
\hline Prethodno priopćenje & 20 & 74,10 & 7 & 25,90 \\
\hline Izlaganje sa skupa & 2 & 100,00 & 0 & 0,00 \\
\hline Stručni prikaz & 1 & 100,00 & 0 & 0,00 \\
\hline Ukupno & 229 & 89,09 & 25 & 10,81 \\
\hline
\end{tabular}

\section{Analiza autora i ustanova}

Standardni model autorstva u znanstvenom publiciranju podrazumijeva objavljivanje rada kojeg potpisuje jedan ili više autora. Specifičnost suvremenog autorstva u većini znanstvenih disciplina i područja je postupno smanjenje broja jednoautorskih radova. Autorstvo postaje kolektivna aktivnost, s velikim brojem koautora (Jokić, 2005.). Analiza autorstva je važna jer odražava suvremene komunikacijske obrasce, prikazuje produktivnost i suradnju među istraživačima. Dakle, podatci o autorstvu mogu pomoći u procjeni rezultata na individualnoj, organizacijskoj i znanstvenoj razini. Podatci o autorima analizirani su prema: broju autora u pojedinim člancima prema godinama izlaženja, prema kategorizaciji članaka, prema instituciji iz koje dolaze te prema zemlji iz koje dolaze.

Pojam suradnje među znanstvenicima odnosi se na zajednički rad istraživača u svrhu postizanja zajedničkog cilja koji je otkrivanje novih spoznaja i stjecanje znanja (Jokić, 2005.). U posljednjih nekoliko desetljeća dolazi do dramatičnog povećanja znanstvene suradnje, što se očituje u sve većem apsolutnom i relativnom broju višeautorskih radova u odnosu na jednoautorske radove (Zauder, 2014.). Koautorstvo se smatra formalnom manifestacijom intelektualne suradnje u znanstvenim istraživanjima (Acedo et al., 2006.). U većini slučajeva predstavlja sudjelovanje dva ili više autora u produkciji objavljenog rada. Koautorstvo na objavljenim radovima često se koristi kao indikator suradnje.

Tablica 2. Broj radova prema broju autora

Table 2. Number of articles vs. number of authors

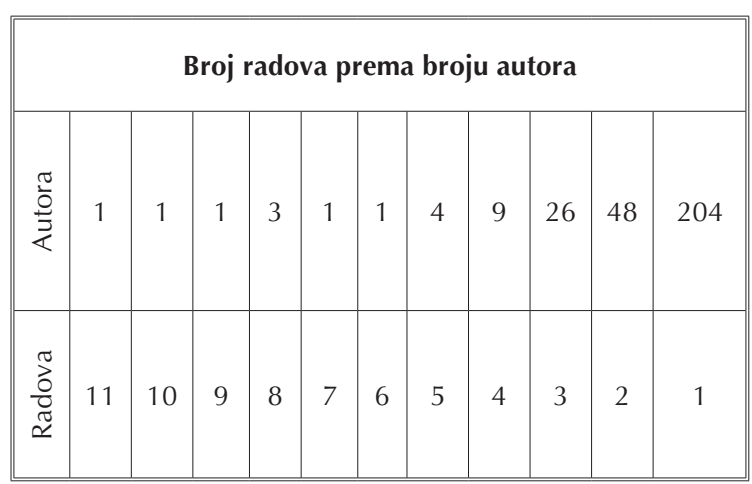


Distribucija objavljenih radova neke skupine znanstvenika je izrazito asimetrična, gotovo eksponencijalna. Shodno tome, za većinu radova odgovoran je mali udio znanstvenika. Spomenuta pravilnost se zove Lotkin zakon. Lotkin zakon je pak posebna upotreba Zipfovog zakona koji je originalno formuliran kako bi opisao frekvencije pojavljivanja riječi u jeziku. Isti princip je u ekonomiji poznat kao Paretova distribucija. U Tablici 2. prikazana je distribucija objavljenih radova. Iz Tablice 2 može se iščitati da je jedan autor objavio 11 radova, jedan objavio 10 radova, jedan 9 radova, tri autora po 8 radova, jedan

Tablica 3. Najproduktivniji autori

Table 3. The most productive authors

\begin{tabular}{|c|c|c|c|c|c|c|c|}
\hline \multirow{2}{*}{ Autor } & \multirow{2}{*}{$\begin{array}{c}\text { Sveukupno } \\
\text { radova }\end{array}$} & \multicolumn{6}{|c|}{ Autora po kategoriziranom radu } \\
\hline & & jedan autor & dva autora & tri autora & četiri autora & pet autora & šest autora \\
\hline Zavalić, Marija & 11 & 5 & 4 & 1 & 1 & 0 & 0 \\
\hline Mijović, Budimir & 10 & 1 & 3 & 5 & 1 & 0 & 0 \\
\hline Učur, Marinko Đ & 9 & 9 & 0 & 0 & 0 & 0 & 0 \\
\hline Pejnović, Natalija & 8 & 3 & 1 & 2 & 0 & 0 & 2 \\
\hline Mustajbegović, Jadranka & 8 & 1 & 2 & 1 & 1 & 2 & 1 \\
\hline Bogadi-Šare, Ana & 8 & 1 & 5 & 0 & 0 & 0 & 2 \\
\hline Knežević, Bojana & 7 & 0 & 0 & 0 & 2 & 2 & 3 \\
\hline Palačić, Darko & 6 & 4 & 0 & 2 & 0 & 0 & 0 \\
\hline Milošević, Milan & 5 & 0 & 1 & 0 & 1 & 2 & 1 \\
\hline Markič, Mirko & 5 & 0 & 2 & 2 & 1 & 0 & 0 \\
\hline Kulišić, Damir & 5 & 5 & 0 & 0 & 0 & 0 & 0 \\
\hline Janev Holcer, Nataša & 5 & 0 & 1 & 1 & 2 & 1 & 0 \\
\hline
\end{tabular}

Tablica 4. Broj autora u kategorizranim radovima po godinama

Table 4. Number of authors per article and year

\begin{tabular}{|c|c|c|c|c|c|c|c|c|c|}
\hline \multirow{2}{*}{ Godina } & \multirow{2}{*}{$\begin{array}{c}\text { Broj } \\
\text { radova }\end{array}$} & \multicolumn{6}{|c|}{ Autorstvo } & \multirow{2}{*}{$\begin{array}{l}\text { Sveukupno } \\
\text { autora }\end{array}$} & \multirow{2}{*}{$\begin{array}{l}\text { Prosječan } \\
\text { br. autora }\end{array}$} \\
\hline & & jedan autor & dva autora & tri autora & četiri autora & pet autora & šest autora & & \\
\hline 2005. & 22 & 12 & 7 & 3 & 0 & 0 & 0 & 35 & 1,59 \\
\hline 2006. & 16 & 12 & 2 & 1 & 1 & 0 & 0 & 23 & 1,43 \\
\hline 2007. & 25 & 10 & 8 & 6 & 1 & 0 & 0 & 48 & 1,92 \\
\hline 2008. & 24 & 10 & 6 & 8 & 0 & 0 & 0 & 46 & 1,66 \\
\hline 2009. & 28 & 15 & 4 & 4 & 1 & 3 & 1 & 60 & 2,14 \\
\hline 2010. & 21 & 9 & 6 & 5 & 0 & 1 & 0 & 41 & 1,95 \\
\hline 2011. & 26 & 10 & 7 & 5 & 4 & 0 & 0 & 55 & 2,11 \\
\hline 2012. & 23 & 9 & 7 & 4 & 0 & 1 & 2 & 52 & 2,26 \\
\hline 2013. & 22 & 9 & 4 & 4 & 3 & 1 & 1 & 52 & 2,36 \\
\hline 2014. & 21 & 10 & 5 & 4 & 1 & 1 & 0 & 41 & 1,95 \\
\hline 2015. & 22 & 9 & 4 & 5 & 3 & 1 & 0 & 49 & 2,23 \\
\hline Sveukupno & 250 & 115 & 60 & 49 & 14 & 8 & 4 & 502 & 2,00 \\
\hline
\end{tabular}

7 radova itd. Najproduktivniji autori su prikazani u Tablici 3.

Multidisciplinarnost i interdisciplinarnost znanosti mogu se očitovati i u broju autora koji zajednički surađuju na radu. Analizirane radove potpisuje ukupno 502 autora. Gotovo polovina radova je jednoautorska (46\%). Radova u koautorstvu dvaju autora je $24 \%$, u koautorstvu triju autora 19,6\%, u koautorstvu četriju autora 5,6 \%, u koautorstvu pet autora 3,2 \% te u koautorstvu šest autora 1,6 \% (Tablica 4.). Prosječan broj autora po članku je 2,00. 
Promatrajući broj autora u odnosu na kategorizirane radove (Tablica 5.), uočljivo je da je kod izvornih znanstvenih radova samo 14,28 \% jednoautorskih radova te da je prosječan broj autora u toj kategoriji 2,77. Jednoautorski radovi najzastupljeniji su u kategoriji stručnih radova, 57,5 \%, te je prosječan broj autora u toj kategoriji 1,73. Pregledni radovi imaju 56,79 \% jednoautorskih radova te je prosječan broj autora u toj kategoriji 2,30. Prethodna priopćenja imaju 47,82 \% jednoautorskih radova te je prosječan broj autora u toj kategoriji 1,91.

Analizirajući autorstvo u odnosu na godine, pretpostavka je da će broj višeautorskih radova rasti, odnosno da će padati broj jednoautorskih radova. No, za cijelo analizirano razdoblje jednoautorski radovi zastupljeni su s približno polovinom radova u svakom volumenu. Najveće odstupanje je 2013. godine kada je više od polovice radova višeautorsko.

Što se tiče porijekla autora, u cjelini gledano, dvije trećine autora su domaći autori. Distribucija porijekla autora unutar godina izlaženja prikazuje slične rezultate (slika 3.).

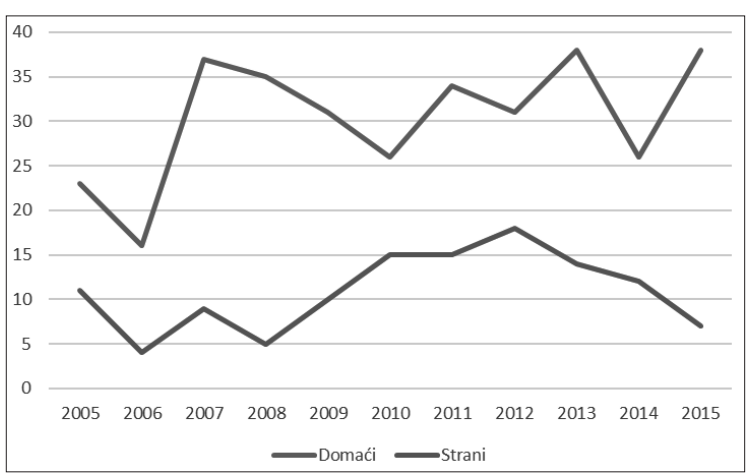

Slika 3. Porijeklo autora

Figure 3. Origin of authors

\section{Institucije}

Promatrajući institucije iz kojih autori dolaze, očekivano najveći broj autora je s raznih domaćih i stranih sveučilišta, znanstvenih instituta, državnih institucija. Svukupno institucija iz kojih dolaze autori je 144. Institucije koje po učestalosti zauzimaju prvih deset mjesta (Tablica 6.) odgovorne su za $55 \%$ radova objavljenih u časopisu.

Tablica 5. Broj autora prema kategorizaciji rada

Table 5. Number of authors by article categorization

\begin{tabular}{|c|c|c|c|c|c|c|c|}
\hline \multirow{2}{*}{ Kategorija rada } & \multicolumn{6}{|c|}{ Broj autora } & \multirow{2}{*}{ Ukupno } \\
\hline & jedan autor & dva autora & tri autora & četiri autora & pet autora & šest autora & \\
\hline Izvorni znanstveni rad & 9 & 19 & 20 & 9 & 4 & 2 & 63 \\
\hline Pregledni rad & 46 & 19 & 11 & 3 & 0 & 2 & 81 \\
\hline Prethodno priopćenje & 11 & 6 & 4 & 1 & 1 & 0 & 23 \\
\hline Stručni rad & 46 & 16 & 14 & 1 & 3 & 0 & 80 \\
\hline Izlaganje sa skupa & 2 & 0 & 0 & 0 & 0 & 0 & 2 \\
\hline Stručni prikaz & 1 & 0 & 0 & 0 & 0 & 0 & 1 \\
\hline Ukupno & 115 & 60 & 49 & 14 & 8 & 4 & 250 \\
\hline
\end{tabular}


Tablica 6. Prvih deset ustanova po učestalosti objavljivanja u časopisu

Table 6. Top ten institutions which have published in the journal

\begin{tabular}{|c|c|c|}
\hline Redni broj & Naziv ustanove & Učestalost \\
\hline 1 & Hrvatski zavod za zaštitu zdravlja i sigurnost na radu, Zagreb (RH) & 52 \\
\hline 2 & Tekstilni fakultet, Zagreb (RH) & 31 \\
\hline 3 & Sveučilište u Zagrebu Medicinski fakultet, ŠNZ “Andrija Štampar”, Zagreb, (RH) & 29 \\
\hline 4 & Institut za medicinska istraživanja i medicinu rada, Zagreb (RH) & 20 \\
\hline 5 & Veleučilište u Karlovcu, Karlovac (RH) & 18 \\
\hline \multirow{2}{*}{6} & KBC Zagreb, Zagreb (RH) & 13 \\
\hline & Fakultet strojarstva i brodogradnje, Zagreb (RH) & 13 \\
\hline 7 & Tehnički fakultet Bihać, Bihać, (BiH) & 11 \\
\hline \multirow{3}{*}{8} & Department of Mechanical Engineering, Federal University of Agriculture, P. M. B. 2240, Abeokuta, & 9 \\
\hline & HP-Hrvatska pošta d.d., Zagreb, (RH) & 9 \\
\hline & Pravni fakultet Sveučilišta u Rijeci, Rijeka (RH) & 9 \\
\hline \multirow{3}{*}{9} & Fakultet prometnih znanosti, Zagreb, (RH) & 7 \\
\hline & Fakultet za promet i komunikacije, Sarajevo, $(\mathrm{BiH})$ & 7 \\
\hline & Policijska akademija MUP-a, Zagreb (RH) & 7 \\
\hline \multirow{6}{*}{10} & Euronitka, Ljubljana (SLO) & 5 \\
\hline & Grafički fakultet Sveučilišta u Zagrebu, Zagreb, (RH) & 5 \\
\hline & $\begin{array}{l}\text { Institut Ruđer Bošković, } \\
\text { Zagreb, (RH) }\end{array}$ & 5 \\
\hline & $\begin{array}{l}\text { Institut za antropologiju, } \\
\text { Zagreb, (RH) }\end{array}$ & 5 \\
\hline & Medicinski fakultet Univerziteta u Tuzli, Tuzla, (BiH) & 5 \\
\hline & Visoka škola za sigurnost na radu, Zagreb, $(\mathrm{RH})$ & 5 \\
\hline
\end{tabular}

\section{Vidljivost časopisa Sigurnost u sekundarnim izvorima}

Vidljivost časopisa Sigurnost znanstvenostručnoj zajednici kojoj je namijenjen postignuta je zastupljenošću u značajnim sekundarnim disciplinarnim bazama podataka. U nekim disciplinarnim bazama indeksiran je selektivno, što znači, zastupljeni su pojedini radovi koji tematski odgovaraju određenoj bazi podataka. To su baze podataka: Civil Engineering Abstracts, Mechanical \& Transportation Engineering Abstracts, ProQuest Materials Research Professional te Risk Abstracts. U bazi podataka ProQuest Biological \& Health Science Professional časopis Sigurnost indeksiran je od 1992. Međutim, značaj odnosno međunarodnu vidljivost zainteresiranoj populaciji, časopis Sigurnost postigao je zastupljenošću u multidisciplinarnoj bibliografskoj i citatnoj bazi podataka Scopus. Osim u Scopusu časopis je indeksiran u cijelosti i u multidisciplinarnoj bazi podataka Academic Search Complete (ASC) iz korpusa EBSCO-vih baza podataka. Radovi časopisa Sigurnost indeksirani su u Scopusu od vol. 51, 2009. godine., a u ASC, od vol. 50, 2008. godine.

Svoju vidljivost časopis Sigurnost naročito je povećao i osiguravanjem pristupa cjelovitim tekstovima objavljenih radova dostupnih preko Portala znanstvenih časopisa Republike Hrvatske - Hrčak (http://hrcak.srce.hr/sigurnost) od vol. 47 (2005), br. 1. U Hrčak je uključen 1. ožujka 2006. godine.

Ukupna posjećenost časopisa Sigurnost na portalu Hrčak od 7. ožujka 2007 od kada se prate statistički pokazatelji na portalu Hrčak (http://hrcak.srce.hr) do 1. ožujka 2017. godine je 772.255, što svrstava časopis na 32. mjesto svih časopisa uključenih u portal Hrčak, kojih je 
početkom ožujka 2017. uključeno 432. Prema broju posjećenosti priloga od 530.044. u promatranom razdoblju, časopis Sigurnost je na 26. mjestu svih časopisa. Područja pokrivenosti časopisa Sigurnost na portalu Hrčak su: tehničke znanosti, javno zdravstvo i zdravstvena zaštita, pravo i psihologija.

Prema znanstvenim područjima časopis Sigurnost u području tehničkih znanosti, gdje je zastupljeno 72 časopisa, po ukupnom broju posjećenosti kao i po posjećenosti priloga nalazi se na visokom 5. mjestu.

U području biomedicine i zdravstva, u okviru kojega se nalazi javno zdravstvo i zdravstvena zaštita s ukupno 64 časopisa uključenih u Hrčak, časopis Sigurnost nalazi se na 10. mjestu po ukupnoj posjećenosti i posjećenosti priloga. U sklopu društvenih znanosti od ukupno 179 časopisa Sigurnost se nalazi na veoma dobroj 11. poziciji po ukupnom broju posjećenosti te na 9. mjestu po posjećenosti priloga. Prema portalu Hrčak, statistikama su obuhvaćena otvaranja web stranica časopisa, sveščića, članka (bibliografskog zapisa) te priloga u punom tekstu (PDF). Suma tih brojeva daje ukupnu posjećenost časopisa. Iz navedenih statističkih pokazatelja dostupnih na portalu Hrčak može se zaključiti da se radovi objavljeni u časopisu Sigurnost redovito pregledavaju i preuzimaju, te da su teme koje obrađuju, osim znanstvenicima koji objavljuju radove u časopisima indeksiranim u citatnim indeksima značajni i širem krugu zainteresiranih čitatelja koji objavljuju rjeđe ili svoje radove objavljuju u časopisima koji nisu pokriveni citatnim indeksima pa njihovo eventualno citiranje radova iz časopisa Sigurnost nije vidljivo.

\section{Analiza citiranosti}

Procjena kvalitete znanstvene produktivnosti znanstvenika kao i znanstveno-stručnih časopisa danas se često provodi kvantitativnim vrednovanjem njihove kvalitete koja se u većini slučajeva prikazuje bibliometrijskim parametrima, tj. citatnim analizama. Prema podacima o broju znanstvenih radova, broju dobivenih citata, zastupljenim autorima mjeri se znanstvena produktivnost i odjek pojedinaca, a također i status časopisa u međunarodnoj znanstvenoj zajednici. Citatnim analizama moguće je ustanoviti vodeće znanstvenike i publikacije u pojedinim znanstvenim područjima te ih vrednovati brojem i vrstom dobivenih citata.

Citiranost radova objavljenih u časopisu Sigurnost te h-indeks, iako časopis nije indeksiran u Thomson Reutersovim (od 2016. Clarivate Analytics) citatnim indeksima, moguće je provjeriti pretražujući po naslovu časopisa preko Cited Reference Search (WoSCC from All databases) koja daje podatak o citiranosti i onih radova koji nisu indeksirani u WoS-ovim bazama, a citirali su ih autori koji su svoje radove objavili u časopisima koji su zastupljeni u Clarivate Analyticsovim citatnim indeksima. Pretraživanje citata koje su dobili radovi objavljeni u časopisu Sigurnost od kada je počeo izlaziti, provedeno je u ožujku 2017. godine, a pretraživanje časopisa provodilo se po naslovu časopisa (Sigurnost). Na taj način utvrđeno je da je ukupan broj citiranih radova njih 52, dobilo ukupno 63 citata. Prosječan broj citata po članku prema WoSCC citatnoj bazi je 0,25 .

Prema broju citata koje su dobili najcitiraniji radovi, može se izračunati h-indeks, broj kojega je E. Hirsch u svojem radu 2005. godine opisao kao pokazatelj znanstvenog odjeka istraživača (Hirsch, 2005.). H-indeks nastoji objediniti kvantitativni doprinos znanstvene djelatnosti prikazan brojem objavljenih radova i kvalitativni odjek prikazan brojem citata koji je dobio određeni objavljeni rad. Ovaj indikator može se koristiti kao mjera kvalitete rada znanstvenika, kao i grupe znanstvenika instituta, sveučilišta, zemlje, a također i časopisa. $\mathrm{H}$-indeks nalazi se u citatnoj kolekciji WoSCC u sklopu podataka o citiranosti (Citation Report) koji nudi statističke podatke o broju publiciranih radova indeksiranih u citatnim indeksima WoSCC te broju dobivenih citata. H-indeks časopisa Sigurnost u promatranom razdoblju izračunat je iz Cited Reference Search (WoSCC from All databases) te je iznosio 2, što znači da su dva rada citirana najmanje dva puta. Svi ostali radovi citirani su 2 i manje puta. Raspon citiranih referenci je od 1975. do 2015., a 52 rada iz časopisa Sigurnost citirali su autori 48 radova iz različitih časopisa. $U$ promatranom razdoblju niti jedan od radova koji su citirali radove iz časopisa Sigurnost ne pripada promatranom časopisu. 
Časopis Sigurnost indeksiran je u citatnoj bazi Scopus od 2009. godine. Scopus je danas, najveća multidisciplinarna, bibliografska i citatna baza podataka koja daje podatke o citiranosti pojedinih autora i radova, analizira časopise te za njih kao i za autore izračunava h-indeks. Za časopise na svojim stranicama daje i podatak o SJR indikatoru (Scimago Journal \& Country Rank) te podatak o SNIP indikatoru (Source normalized impact per paper); (Macan, Petrak, 2015: 42), a od kraja 2016. uveden je novi indikator CiteScore (Scopus Journal Metrics, 2016). CiteScore mjeri prosječni broj dobivenih citata po dokumentima objavljenim u indeksiranoj publikaciji.

U razdoblju od 2009. do ožujka 2017. Scopus je indeksirao ukupno 374 kategoriziranih radova i priloga časopisa Sigurnost (Scopus, 2017.). U vrijeme pretraživanja zadnji je indeksiran broj 4. iz vol. 58/2016. godine. Broj radova i priloga u časopisu ne podudara se s brojem indeksiranih jedinica u Scopusu. Scopus je indeksirao sve kategorizirane radove od 2009., te one priloge koji su dostupni na portalu Hrčak. Prema analizi objavljenih dokumenata u razdoblju od 2009. do 2015. bilo je ukupno 432 dokumenta, a u Scopusu u tom razdoblju zastupljeno je 330 jedinica, što znači da Scopus ne indeksira časopis od korica do korica, već kategorizirane radove i pojedine priloge. Baza indeksira sve kategorizirane radove, osim ako se dogodi da koji rad greškom izostane, kao što je slučaj s radom iz 2014. godine br. 2 na stranicama 95-112. U tom slučaju potrebno je o propustu obavijestiti Scopus.

U ožujku 2017. od ukupno 374 dokumenata časopisa Sigurnost citirano je 39 radova koji su ukupno dobili 57 citata, bez samocitata 41, h-indeks je 2, kao i u WoSCC. Najcitiraniji rad je Zdravstveni djelatnici u bolnicama i stres na radu: istraživanje u Zagrebu iz 2009. godine, citiran je 6 puta. Od ostalih radova jedan rad dobio je 3 citata, a ostali manje od tri. Prosječan broj citata po članku prema Scopus citatnoj bazi je 0,15. Manji prosječan broj citata prema Scopus bazi u odnosu na WoSCC je za očekivati jer je u Scopusu indeksiran mali raspon godina časopisa Sigurnost.

\section{ZAKLJUČAK}

Časopis Sigurnost neprekidno izlazi od 1959. godine. U prvom redu obuhvaća tematska polja zaštite na radu, zaštite od požara, sigurnosti u prometu, zaštitu okoline i medicinu rada. Najstariji je znanstveno-stručni časopis ove tematike u Hrvatskoj, a može se reći i na prostoru jugozapadne i jugoistočne Europe. Sigurnost izlazi četiri puta na godinu. Bibliometrijskom analizom dobiveni su rezultati da je časopis u jedanaestogodišnjem razdoblju (2005.-2015.) objavio 250 kategorizirana rada, od toga najzastupljeniji su pregledni radovi $(32,4 \%)$, zatim stručni radovi zastupljeni su s udjelom od $32 \%$, izvorni znanstveni radovi s udjelom od 25,2 \%, prethodna priopćenja s udjelom od 9,2\%, izlaganja sa skupa s udjelom od $0,8 \%$ dok je najmanje radova kategorizirano kao stručni prikaz (0,4\%). Velika većina radova objavljena je na hrvatskom jeziku (90\%), što pokazuje da je časopis ponajprije namijenjen i interesantan znanstvenicima Hrvatske i šire regije.

Podaci o ukupnoj posjećenosti i preuzimanjima priloga časopisa Sigurnost na portalu Hrčak, koji ga svrstavaju u prvih deset časopisa prema znanstvenom području koje časopis pokriva, u području tehničkih znanosti čak prvih pet, govore u prilog značaja časopisa te zanimljivosti tema koje obuhvaća.

\section{LITERATURA}

Acedo, F. J., Barroso, C., Casanueva, C., Galán, J. L.: CoAuthorship in Management and Organizational Studies: An Empirical and Network Analysis, Journal of Management Studies, 43, 2006., 5, 957-983. Dostupno na: https://www.researchgate.net/profile/FrancisCo_Acedo/publication/228253542_Co-Authorship_in_Management_and_Organizational_ Studies_An_Empirical_and_Network_Analysis/ links/00b7d51aa291c905b4000000.pdf, pristupljeno 6.5.2017.

Borić, V.: Analiza citata radova objavljenih u časopisu Acta stomatologica Croatica zabilježenih u bazi podataka Web of Science, Acta stomatologica Croatica, 2, 2008., 42, 123139. Dostupno na: http://hrcak.srce.hr/index. 
php?show=clanak\&id_clanak_jezik=40800, pristupljeno 6.5.2017.

Borić, V.: Znanstvena aktivnost na području botanike mjerena kroz časopis Acta Botanica Croatica, Acta botanica Croatica, 51, 1992., 169176. Dostupno na: http://hrcak.srce.hr/index. php?show=clanak\&id_clanak_jezik=235620, pristupljeno 6.5.2017.

Borić, V., Strujić, M.: Bibliometrijska analiza Acta stomatologica Croatica za razdoblje od 1987. do 2006. godine, Acta stomatologica Croatica, 4, 2006., 40, 336-346. Dostupno na: http:// hrcak.srce.hr/index.php?show=clanak\&id_clanak_jezik=17935, pristupljeno 6.5.2017.

Dukić, Z.: Mjesto sociologije u sistemu znanosti; Citatna analiza triju domaćih socioloških časopisa, Revija za sociologiju, 21, 1990., 3, 455465, Dostupno na: http://hrcak.srce.hr/index. php?show=clanak\&id_clanak_jezik=228892, pristupljeno 6.5.2017.

Godin, B.: On the origins of bibliometrics, Scientometrics, 68, 2006., 1, 109-133. Dostupno na: http://www.csiic.ca/PDF/Godin_33.pdf, pristupljeno 6.5.2017.

Hirsch, J.E.: An index to quantify an individual's scientic research output. U: Proc Natl Acad Sci USA, 102 (46), 2005., str. 16569-16572. Dostupno na: http://www.ncbi.nlm.nih.gov/pmc/ articles/PMC1283832/. Pristupljeno: 15.12.2016.

Jokić, M., Sirotić, G.: The communicability of the journal Acta botanica croatica over the 19912000 period, Acta Botanica Croatica, 61, 2002, 2, 221-230, Dostupno na: http://hrcak.srce.hr/ index.php?show=clanak\&id_clanak_jezik=5775, pristupljeno 6.5.2017.

Jokić, M. i Zauder, K.: Bibliometrijska analiza časopisa Sociologija sela / Sociologija i prostor u razdoblju 1963.-2012., Sociologija i prostor, 51, 2013, 196 (2), 331-349. Dostupno na: http://hrcak.srce.hr/index.php?show=clanak\&id_clanak_ jezik=161510, pristupljeno 6.5.2017.

Jokić, M.: Bibliometrijski aspekti vrednovanja znanstvenog rada. Sveučilišna knjižara, Zagreb, 2005.

Jokić, M.: Časopis Tekstil u pedesetogodišnjem razdoblju od 1952. do 2000. godine - neki od bibliometrijskih pokazatelja, Tekstil, 50, 2001., 12, 614-622.
Jokić, M., Andreis, M. i Klaić, B.: Pedeset godina Kemije u industriji - bibliometrijski i scientometrijski prikaz, Kemija u industriji, 51, 2002., 3: 116-122.

Krajna, T., Petrak, J.: Bibliometrijske značajke časopisa Strojarstvo u razdoblju od 1992. do 2001. godine, Strojarstvo, časopis za teoriju i praksu u strojarstvu, 1-3, 2004., 46.

Macan, B., Petrak, J.: Bibliometrijski pokazatelji za procjenu kvalitete znanstvenih časopisa, u: Hrvatski znanstveni časopisi: iskustva, gledišta, mogućnosti / Hebrang Grgić, Ivana (ur.). Školska knjiga, Zagreb, 2015.

Macan, B.: Model sustava informacija o znanstvenoj djelatnosti za hrvatsku akademsku zajednicu, doktorski rad, Zagreb, 2015.

Martek, A., Šute, S.: Bibliometrijska analiza časopisa Arhivski vjesnik u razdoblju od 2001. do 2009., Arhivski vjesnik, 53, 2010., 165176. Dostupno na: http://hrcak.srce.hr/index. php? show=clanak\&id_clanak_jezik=93686, pristupljeno 6.5.2017.

Pehar, F.: Od statističke bibliografije do bibliometrije. Povijest razvoja kvantitativnog pristupa istraživanju pisane riječi, Libellarium, 3, 2010., 1, 1-28. Dostupno na: http://hrcak.srce.hr/index. php?show=clanak\&id_clanak_jezik=110191, pristupljeno 6.5.2017.

Petrak, J.: Bibliometrijski pokazatelji u ocjenjivanju znanstvenog rada. 2. Citati i njihova analiza. Liječnički vjesnik, 5-6, 2001., 123, 129134

Petrak, J.: Bibliometrijski pokazatelji u ocjenjivanju znanstvenog rada. 1. Objavljivanje i ocjenjivanje rezultata znanstvenog rada, $L i$ ječnički vjesnik, glasilo Hrvatskoga liječničkog zbora, 3-4, 2001., 123, 77-81.

Portal Hrčak, dostupno na: http://hrcak.srce.hr/index.php?show=posjecenostc a sopisa $\&$ mjesec $c_{-}$od $=1 \&$ godina o d $=2007 \& \mathrm{mjesec} \mathrm{c}_{-} \mathrm{do}=1 \&$ godin a do=2017\&podrucje=0, pristupljeno: 1.3.2017.

Scopus Journal Metrics, 2016., dostupno na: https://journalmetrics.scopus.com/, pristupljeno 9.3.2017.

Scopus, 2017. dostupno na: https://www.scopus.com/, pristupljeno 09.3.2017. 
Švenda Radeljak, K.: Journal Social Work-the first decade (1960-1969), Ljetopis socijalnog rada, 13, 2006., 1, 115-132. Dostupno na:http://hrcak. srce.hr/index.php?show=clanak\&id_clanak_jezik=11447, pristupljeno 6.5.2017.
Zauder, K.: Razvoj scientometrije praćen kroz časopis Scientometrics od početka izlaženja 1978. do 2010. godine, doktorski rad, Zagreb, 2014.

\section{BIBLIOMETRIC ANALYSIS OF THE JOURNAL 'SIGURNOST' FROM 2005 TO 2015}

SUMMARY: The paper analyzes the articles published in the Journal Safety by using the basic bibliometric indicators. The sample consisted of 250 categorized articles published over a ten year period, from 2005 until 2015. The analysis has shown that the most common articles were review papers $(32.4 \%)$, then professional papers $(32 \%)$, original scientific papers $(25.2 \%)$, preliminary notes (9.2\%), conference papers (0.8\%) and professional views (0.4\%). Most articles were written in the Croatian language $(90 \%)$ indicating a regional character of the Journal. Journal Safety is included in the multidisciplinary bibliographic and citation database Scopus from vol. 51, 2009, multidisciplinary database Academic Search Complete (ASC) from EBSCO Corps-led database of $50 \mathrm{vol}$. 2008. Also, it is fully indexed in the disciplinary database ProQuest Biological Science \& Health Professional completely from 1992. Visibility Magazine Security is enabled by providing access to full texts of publications available through the Portal of Scientific Journals of Croatia - Hrčak from vol. 47 (2005), No. 1. was included in Hrčak on March 1, 2006.

Key words: journal Safety, bibliometric indicators, paper analysis, Croatia 